\title{
HOW DOES THE ROMANIAN ECONOMIC ENVIRONMENT FACE THE CHALLENGES GENERATED BY THE INGREASED NUMBER OF PENSIONERS?
}

\author{
Bianca AVRAM-POP ${ }^{\mathrm{a}, *}$, Constantin CUCOȘEL ${ }^{\mathrm{b}}$ \\ a), b) Technical University of Cluj-Napoca, North University Center in Baia Mare, \\ Faculty of Sciences, Baia Mare, Romania
}

Please cite this article as:

Article History:

Avram-Pop, B. and Cucoșel, C., 2018. How does the Received: 19 February 2018 Romanian economic environment face the challenges generated by the increased number of pensioners? Accepted: 28 March 2018

Review of Economic Studies and Research Virgil Madgearu, 11(1), pp.5-20.

doi: 10.24193/RVM.2018.11.18.

Abstract: The phenomenon of population aging characterized in this paper as the pensioner-employee ratio is a frequent issue of focus for scientists. Despite the fact that Romania was under a communist regime whose policy was pro natality, almost 30 years after its downfall one can notice the occurrence of this negative demographic phenomenon. This paper approaches the effects of population aging on four economic sectors in Romania: agriculture, industry, services and manufacturing. We began this analysis by representing the variables graphically, and after we explained their evolution and the descriptive statistics, we identified the correlations between the aging population and the variables used for the economic description. The outcomes have implications in the future economic development in Romania, and can be used by the decision-makers in order to implement laws which could reduce the negative effects of population aging.

Key words: aging population; agriculture; manufacturing; industry JEL Classification: EOO

(C) 2018 Alma Mater Publishing House. All rights reserved.

* Corresponding author. E-mail address: avrambia@gmail.com. 


\section{References}

1. Bloom, D.E., Canning, D. and Malaney, P., 2000. Demographic Change and Economic Growth in Asia. Population and Development Review, 26, pp.257-290.

2. Bloom, D.E., Canning, D. and Fink, G., 2011. Implications of population aging for economic growth. NBER Working Paper, no. 16705. 10.3386/w16705.

3. Bloom, D.E. and Williamson, J.G., 1998. Demographic transitions and economic miracles in emerging Asia. The World Bank Economic Review, 12(3), pp.419-455.

4. Calasanti, T.M. and Slevin, K.F., 2001. Gender, Social Inequalities and Aging. Lanham: Rowman and Littlefield Publishers Inc.

5. Cutler, S.J., 2012. Long-term implications for widowhood of Romania's Decree No.770. Revista de Asistență Socială, 1, pp.113-123.

6. Department of Economic and Social Affairs, 2016. International Migration Report 2015. New York: United Nations.

7. Giannakouris, K., 2008. Ageing characterizes the demographic perspectives of the European societies. Eurostat: Statistics in Focus, pp.1-12.

8. Gray, C. and Weig, D., 1999. Pensions system issues and their relation to economic growth (Consulting assistance on economic reform II. Discussion Paper 41), [online] Available at: <http://www. cid.harvard.edu/caer2/htm/content/papers/confpubs/paper41/>.

9. Greenspan, A., 2003. Aging global population: testimony before the Special Committee on Aging, U.S. Senate, February 27, 2003, Speech 21, Board of Governors of the Federal Reserve System (U.S.).

10. Hagemejer, K., 1999. The Transformation of Social Security in Central and Eastern Europe. In: K. Müller, A. Ryll, A. and H.J. Wagener (eds.) Transformation of Social Security: Pensions in Central-Eastern Europe. Contributions to Economics. Heidelberg: Physica, pp.31-58.

11. Hoff, A., 2011. Population ageing in Central and Eastern Europe: Societal and policy implications. Farnham: Ashgate Publishing.

12. National Institute of Statistics, 2012. Statistical yearbook 2011.

13. National Institute of Statistics, 2013. Population and household census. 
14. Peterson, P.G., 1999. Gray dawn: The global aging crisis. Foreign Affairs, 78(1), pp.42-55.

15. Preda, M., Dobos, C. and Grigoras, V., 2004. Romanian Pension System during the Transition: Major Problems and Solutions. European Institute of Romania.

16. Preda, M., Pop, L.M. and Bocioc, F., 2006. The Gender Dimensions of Social Security Reform in Romania. International Labour Office, pp.11-91.

17. Tyers, R. and Shi, Q., 2007. Demographic Change and policy responses: Impications for the global economy. The World Economy, 30(4), pp.537-566. 